\title{
ENCONTROS COM PIERRE BOURDIEU E DESTINOS DE SUA OBRA-ENTREVISTA COM GISÈLE SAPIRO
}

Tradução de Eduardo Dimitrov e Maíra Muhringer Volpe

Em 23 de janeiro de 2002 falecia Pierre Bourdieu, recém-aposentado de sua cátedra de sociologia no Collège de France, provocando uma comoção pública que suscitou pronunciamentos de autoridades como as do presidente da República, Jacques Chirac (gaullista histórico), do Primeiro Ministro e opositor do presidente, Lionel Jospin (socialista), de diversos outros representantes eleitos ou simples militantes, bem como de escritores, artistas, cientistas, filósofos e intelectuais das mais variadas procedências e ideologias, tudo com vasta cobertura da mídia. Mas não se imagine haver consenso nacional ou mesmo corporativo de intelectuais; esse sem-número de manifestações reeditou ainda os ataques virulentos expressos publicamente em anos posteriores à greve geral de 1995, como foi o caso de número integral do Le Nouvel Observateur, contendo ataques do editor, mas também do colega da École des Hautes Études en Sciences Sociales (EHESS), Jacques Julliard. ${ }^{1}$ Até o livro intitulado Do jornalismo depois de Bourdieu (Schneidermann, 1999) fez parte do debate. Como toda polêmica ácida, não foi época de tranquilidade, ou de recolhimento, para os adeptos de suas teorias ou admiradores de suas posturas intelectuais. Seria isto uma demonstração suplementar de que a controvérsia aberta é a única forma de se afirmar um novo "paradigma intelectual", algo inerente ao conceito de "campo" proposto pelo "sociólogo maldito"? A polêmica que suscitou, e que ganhou em intensidade nos anos finais de sua existência, prejudicaria o exame detido da pertinência dos enunciados de sua obra voltada para as ciências sociais? 
Se esse alvoroço parece ter acontecido em escala internacional, sobriamente, no Brasil, Luiz Werneck Vianna pôde relembrar as obras nas quais Manuel Palácios, à época doutorando sob sua orientação, realizara contagem bibliométrica, atestando ser Bourdieu o autor mais citado no país, em teses de sociologia, antropologia e ciência política, entre 1990 e 1994, ultrapassando mesmo o trio dos clássicos, Durkheim, Weber e Marx (ver Melo, 1999). Dez anos após seu falecimento, transcrições de seus cursos no Collège de France foram editadas na França, ${ }^{2}$ reunidas em obra discutida em debates públicos, dando origem a um dossiê a respeito de sua atualidade em uma das empresas mais ativas na Internet francesa - Mediapart. Colóquios e livros se sucedem, em escala internacional, sobre o aporte da obra científica de Pierre Bourdieu.

Ainda em 2012, os autores desta introdução puderam reunir-se em $\mathrm{Pa}$ ris, no Centre de Sociologie Européenne (CSE), que fora dirigido por Bourdieu (organismo agora incorporado - por força dos reagrupamentos impostos pelas mudanças institucionais na pesquisa francesa -, ao Centre Européen de Sociologie et de Science Politique - CESSP), e começaram a organizar o conjunto de textos, precedido por entrevista, que se segue. O projeto visou tratar tanto dos destinos internacionais da obra daquele autor - da leitura de seus textos, mas, sobretudo, dos usos de suas questões, de seus métodos e de seus conceitos para enfrentar novos desafios -, quanto de sua recepção e utilização criativa no Brasil. A reflexão deveria abarcar os usos atuais de suas ferramentas teóricas e ainda permitir entender os modos de projeção de sua obra para além da França, sobretudo em direção ao Brasil. Como Renato Ortiz assinala em seu artigo: "Ler Bourdieu no Brasil não é o mesmo que fazê-lo na França". Longe de nós explicitar essa diversidade para buscar ortodoxias ou reforçar centralidades: o modo de pensar a circulação internacional de ideias do sociólogo francês convida a fazer uma sociologia desta diversidade; a entender as facilidades e os obstáculos propriamente sociais à universalização de toda e qualquer forma de pensamento; a entender as possíveis mutações que qualquer proposição científica sofre ao enfrentar a saga de sua generalização. A novidade deste conjunto de textos é justamente a de combinar sociologia histórica da elaboração progressiva de programas de pesquisa, e das hipóteses teóricas que permitiram validar, com os modos de apropriação desses elementos em espaços nacionais muito diferentes de onde foram engendrados.

Dois subconjuntos ajudam a pensar tanto a evolução da pesquisa em seu universo europeu de origem, quanto a evolução dos usos desses instrumentos por pesquisadores brasileiros. A entrevista com Gisèle Sapiro - diretora atual do CSE e do CESSP que o engloba, ex-orientanda de Bourdieu, cientista social proeminente - explicita o modo como foi admitida enquanto doutoranda, como foi levada a redelimitar o escopo e os métodos de sua investigação, como viu seu trabalho ser consagrado como trilha original ao pôr 
à prova o conceito de "autonomia do campo literário", para, finalmente, apresentar um vasto panorama da recepção da obra de Pierre Bourdieu no mundo internacional, particularmente no universo anglo-saxão, onde lecionou seguidamente nos últimos anos.

Por sua vez, Marie-France Garcia-Parpet, pesquisadora do Institut National de la Recherche Agronomique (INRA) e associada ao CSE/CESSP, analisa a sociologia da economia no início e no fim da trajetória de Bourdieu. Os primeiros trabalhos sobre a Argélia permitiram a conformação do conceito de habitus, exatamente por haver discordância absoluta entre os modos de pensar e agir do camponês cabila e os modos de funcionamento da economia de mercado, na qual teria que obter seu sustento, após o reagrupamento efetuado pelas tropas militares francesas desde os anos 1950. A "economia de mercado" se impunha a atores que nunca haviam sido socializados para ela. Após haver estudado os campos literário e científico e examinado os ajustes necessários ao conceito de campo ao tratar da concorrência política, sem nunca ter deixado de chamar a atenção para a especificidade da "economia das trocas simbólicas", Pierre Bourdieu vai aplicar os questionamentos e os métodos elaborados ao exame dos modos de concorrência da economia de mercado no estudo de qualquer campo.

Essas duas contribuições de autoras francesas explicitam certamente debates atuais travados na cena europeia, bem como seus ecos e controvérsias muito além da Europa, sobretudo nos Estados Unidos e no Canadá.

Já o texto de Renato Ortiz, professor de sociologia da Universidade Estadual de Campinas (UNICAMP), de maneira semelhante à primeira parte da entrevista de Gisèle Sapiro, refere-se ao seu encontro com a obra de Bourdieu, e a repercussão desta entre alunos e professores universitários, desde sua chegada à Universidade de Vincennes, marcada profundamente pelas mudanças institucionais que se seguiram a maio de 1968. Ao objetivar seu próprio percurso, como cientista social em formação, Renato Ortiz melhor situa a experiência de ser confrontado a percepções muito diferentes de Bourdieu no Brasil e na França; relembra, ainda, como, em sua volta ao Brasil, aproximou-se de Florestan Fernandes e como chegou a organizar o volume sobre Bourdieu da coleção Grandes Cientistas Sociais, pela Ática (Ortiz, 1983), ressaltando os paradigmas concorrentes no momento daquela edição. Sua perspectiva sublinha a importância da sociologia dos leitores de qualquer autor importado, já que é preciso entender, na área da Educação, como a obra de Paulo Freyre teria sido vista, em finais dos 1970, de modo antagônico àquela do autor francês. Esse contraponto entre a cena brasileira e a cena europeia funciona como convite para reavaliar, ou, ainda, afastar, muitos mal-entendidos acerca dos sentidos das ferramentas teóricas e práticas propostas por Bourdieu, tal qual a percepção do sociólogo como "representante da ideologia da ordem" (imagem jamais existente na Europa). 
José Sergio Leite Lopes reconstitui as carreiras de Alain Touraine e Pierre Bourdieu em suas relações com o mundo internacional, sobretudo suas passagens pelos Estados Unidos, como, e por meio de quem, inspiraram novos programas de pesquisa a respeito das classes populares no Brasil e das mudanças dos modos de pensar e agir das classes dominantes (como entre empresários industriais ou intelectuais). José Sergio demonstra, neste texto, a fecundidade de uma das propostas mais singulares de Pierre Bourdieu ao pensar a extensão de suas ferramentas fundadas no conceito de "campo" para questionar a circulação internacional de ideias e de paradigmas científicos, ou estéticos. Bourdieu já havia constatado, ao estudar os usos de Martin Heidegger na França (ver Bourdieu, 1988), o quanto os significados presentes na cabeça de qualquer participante do campo intelectual alemão ficavam totalmente opacos para os leitores franceses, facilitando implantar sentidos completamente opostos aos originais no universo de chegada. Assim, a recusa de qualquer exportação de pensamento francês, como se fosse um bloco monolítico ou uma propagação de ideias em um vácuo do pensamento, é seguida da proposta de se privilegiar as diferenças sociais e intelectuais no campo intelectual exportador e no campo intelectual importador. A hipótese é a de que a homologia de posições em cada campo nacional informa alianças e clivagens. Qualquer leitor poderá se dar conta da riqueza de detalhes, e da erudição que pôde ser mobilizada por José Sergio Leite Lopes, atestando como esta nova postura permite pôr em relação dados empíricos numerosos e chegar a modelos explicativos de forte densidade.

Talvez valha a pena lembrar que o cruzamento das fronteiras nacionais é característico de todos os participantes desses escritos, inclusive dos organizadores. Gisèle Sapiro, especialmente entrevistada para esta publicação, já veio ao Brasil mais de uma vez, a última delas como conferencista da Associação Nacional de Pós-Graduação e Pesquisa em Ciências Sociais (ANPOCS) em 2012. Ela tem uma trajetória bastante particular. Seu itinerário difere dos comuns, nos círculos intelectuais franceses, em dois sentidos: embora nascida na França, onde passou sua infância, viveu e se formou em Israel; além disso, provém da área de literatura comparada fortemente voltada para os "translations studies" (com interesse pela filosofia da ciência, filosofia da linguagem). Mas foi acolhida na França por Bourdieu e se tornou uma de suas discípulas mais bem-sucedidas: premiada com a medalha de bronze pelo Centre National de la Recherche Scientifique (CNRS) em 2000, é a atual diretora do CESSP. Seu livro mais recente, La responsabilité de l'écrivain (Sapiro, 2011), aborda de forma aprofundada e inovadora os processos movidos contra escritores desde a Revolução Francesa, voltando a pôr à prova a autonomia problemática do "campo literário".

Marie-France Garcia-Parpet, formada em economia em Nanterre, em 1970, começou sua trajetória de pesquisadora junto ao curso de Pós-Gradua- 
ção em Antropologia Social do Museu Nacional, na Universidade Federal do Rio de Janeiro (UFRJ), participando de investigações sobre feiras e mudanças dos modos de dominação das grandes plantações canavieiras do Nordeste. Tornou-se professora no Instituto de Filosofia e Ciências Sociais da mesma Universidade em 1978, onde lecionou por muitos anos no domínio da antropologia social. Realizou pós-doutorado e missões científicas na França, junto à equipe de Pierre Bourdieu, onde investiu em publicações sobre a construção social de mercados, a partir de etnografia de praça mercantil operando através de painel sob comandos computadorizados. Ingressou no INRA em 1994, sem deixar de manter laços de pesquisa constantes com seus colegas no Brasil, investigando a globalização do mercado do vinho.

Renato Ortiz começou por estudos de engenharia antes de ir à França, onde se reconverteu para as ciências sociais, licenciando-se na Universidade de Vincennes. Fez doutorado em antropologia com Roger Bastide, de quem foi um dos últimos alunos na EHESS, prolongando os questionamentos deste autor sobre o lugar da religião de origem africana na construção de espaços sociais para os negros no Brasil. Ao retornar, seu itinerário é também singular: ingressa primeiro na Universidade Federal da Paraíba, de onde partiu para lecionar na Universidade Federal de Minas Gerais (UFMG), chegando, finalmente, à UNICAMP, onde figura como professor titular do Departamento de Sociologia. ${ }^{3}$ Praticamente todo ano faz estadias na França, dando sequência ao amplo espectro de suas pesquisas. Se o primeiro livro foi voltado para sociologia da religião, parte substancial de sua obra problematiza a relação entre cultura, indústria cultural e identidade nacional, desenvolvendo, em época mais recente, estudos sobre globalização do ponto de vista cultural.

Finalmente, José Sergio Leite Lopes fez o "diploma de estudos econômicos gerais" na Universidade de Paris - acompanhando o exílio de seu pai -, e formou-se, em 1970, na Pontifícia Universidade Católica do Rio de Janeiro (PUC-Rio) em Economia. Ingressou, como estudante, no Programa de Pós-Graduação em Antropologia Social (PPGAS) do Museu Nacional (MN/UFRJ) naquele ano, passando a pesquisar grupos operários do Nordeste, objetos de suas monografias de mestrado e doutorado. Sua reconversão de economista a antropólogo foi confirmada ao tornar-se professor de antropologia social do PPGAS/MN, em 1978, no primeiro concurso público desta instituição. Voltou à França, em pós-doutorado supervisionado por Pierre Bourdieu, em finais dos anos 1980, e tornou-se um dos colaboradores de Actes de la Recherche en Sciences Sociales. Como seus colegas franceses Michel Pialoux e Stephane Beaud, a constância temporal das investigações acerca dos mesmos grupos operários, em parceria com Rosilene Alvim, em pesquisas de largo fôlego e profundidade, permitiu objetivar a existência operária no longo prazo, estudando os períodos de auge e de declínio dessa classe no Brasil. Foi nomeado recentemente diretor do Colégio Brasileiro de Altos Estudos (CBAE) da UFRJ. 
Não seria possível, no âmbito deste número, apresentar um panorama exaustivo da recepção da obra de Pierre Bourdieu no mundo internacional, nem mesmo no Brasil. Como relembra Renato Ortiz, no campo da Educação em nosso país muitos foram os empreendimentos de tradução e de desenvolvimento de projetos de pesquisa inspirados na obra de Pierre Bourdieu. Novos usos e novas gerações se apropriam criativamente desse instrumental. Note-se, ainda, a observação que perpassa praticamente todos os testemunhos deste conjunto de textos a respeito do caráter pioneiro de Economia das trocas simbólicas, coletânea organizada por Sergio Miceli em inícios dos anos 1970, calçando seu projeto, de longo prazo, de examinar a recomposição das classes dirigentes no Brasil (Miceli, 2001). Convidado a participar deste número, Sergio Miceli preferiu abster-se, por estar engajado na edição da obra Sobre o Estado, para este mesmo ano. ${ }^{4}$

Esperamos contribuir para aprofundar o debate a respeito da pertinência das ferramentas forjadas por Pierre Bourdieu para a prática de pesquisas em ciências sociais e, como ressalta Gisèle Sapiro no final da entrevista que se segue, para reforçar o diálogo e o trabalho comum entre cientistas sociais inscritos em diferentes universos nacionais. Esperamos, por conseguinte, colaborar para a necessária universalização do discurso científico. 
Afrânio Garcia Jr. \& Elina Pessanha. A primeira parte desta entrevista tem por objetivo compreender seu encontro com Pierre Bourdieu. Se bem entendemos seu trajeto, você fez o ensino superior, antes do doutorado, fora da França. Como foi que veio fazer seu doutorado aqui, na França? Poderia falar um pouco deste seu percurso?

Gisèle Sapiro. Eu nasci na França, mas minha família imigrou para Israel, para Tel Aviv, em 1978. Foi lá, então, que segui meu percurso escolar e fiz meus estudos de literatura comparada e de filosofia na Universidade de Tel Aviv. Fiz BA [Bachelor of Arts] em Literatura Comparada e em Filosofia. Em seguida, fiz MA [Master of Arts] em Literatura Comparada. ${ }^{5}$ Em Tel Aviv trabalhei com o professor Itamar Even-Zohar, amigo de Pierre Bourdieu, e importador e continuador dos formalistas russos. Ele havia desenvolvido a teoria do polissistema e se interessava muito pela sociologia da literatura de Bourdieu. Eles haviam se encontrado e tornaram-se amigos.

A.G. \& E.P. Então já havia uma ligação anterior à sua chegada a Paris?

G.S. Sim. Na verdade, foi dessa maneira que eu descobri Bourdieu, porque Even-Zohar me fez lê-lo. Eu era francesa, então lia em francês. Em relação aos outros estudantes em Israel, eu era a única francesa do Departamento de Literatura Comparada. Ele, portanto, rapidamente me associou ao projeto de tradução dos textos de Bourdieu. Nós líamos Bourdieu, ele nos ensinava Bourdieu. Alguns textos que circulavam não haviam sido publicados, mas circulavam em hebraico. Como eu lia em francês, evidentemente ele me fez ler e também participar do projeto de tradução. Para mim foi uma descoberta inacreditável. Eu nunca tinha feito sociologia.

A.G. \& E.P. Você vinha inteiramente da literatura?

G.S. Sim. Eu fiz literatura comparada e filosofia, sobretudo filosofia da ciência e filosofia da linguagem; isso não é o que se chama de filosofia continental, é mais próximo da filosofia analítica e eu queria fazer uma tese em lógica. Even-Zohar, meu orientador, quando eu lhe disse que queria fazer uma tese em lógica, respondeu: "mas você não trabalhará sobre o mundo?" Isso me fez mudar rapidamente de opinião. No entanto, estava claro para mim que eu não queria continuar a fazer interpretação de texto. Lecionei também no Departamento, era assistente. Existiam duas correntes no Departamento: uma era mais dedicada à poética, e outra, muito forte em narratologia, na qual Menachem Perry era um dos professores, e eu era sua assistente.

Mas muito rapidamente comecei a ensinar também história das ideias políticas, era assistente de Shlomo Sand que estava no Departamento de História. Ele era especialista em história francesa e história intelectual, e eu o encontrei durante o meu mestrado. Meu mestrado tratou da representação nacional nos semanários "político-literários" franceses do período da Liberação, uti- 
lizando noções de Iúri Lotman a respeito da imagem de si de uma cultura. Fiz meu mestrado sobre a reconstrução da imagem de si da França depois da Liberação. Durante um ano examinei detidamente a imprensa de periódicos. Meu professor, Itamar Even-Zohar, já estava um pouco fora da literatura, ele trabalhava cada vez mais sobre a cultura, era isso que o interessava. Ele me incentivou nessa direção e eu me interessei em trabalhar mais com ele do que com a corrente de narratologia, do que continuar fazendo interpretações de texto. Assim descobri a obra de Bourdieu, acho que foi já no final do BA. Isso é um pouco confuso, não tenho uma lembrança muito clara. Mas é certo que, quando estava no mestrado, eu já utilizava Bourdieu. Quando vim fazer meu doutorado, vim para a França por dois meses para trabalhar sistematicamente nos arquivos...

A.G. \& E.P. Isso foi em que ano?

G.S. Isso foi em 1988, 1989 talvez. Vim por um mês, dois meses, eu não lembro mais, para fazer meu trabalho de campo; estava na Biblioteca Nacional para levantar esses semanários "político-literários". Even-Zohar recomendou que eu encontrasse Bourdieu. Pedi-lhe, então, uma entrevista e ele me recebeu. E me lembro, muito claramente, desse encontro, que foi muito impressionante. Ao mesmo tempo, acho que eu não mensurava ainda, na época, a notoriedade internacional de Bourdieu. Era um momento em que ela estava se ampliando. E, então, ele gentilmente me dedicou uma hora, nós conversamos, ele estava apaixonado pelo objeto, mas me disse: "ah, mas precisaria fazer todo um trabalho sobre o campo intelectual sob a Ocupação."

A.G. \& E.P. Então foi desde o início do retorno à França que seu foco se direcionou para essa discussão sobre os escritores durante a Ocupação e a Liberação?

G.S. Eu já tinha trabalhado, nessa época, sobre a Liberação. Trabalhei acerca da representação nacional na imprensa da Liberação e, portanto, Bourdieu me disse que precisaria fazer um trabalho sobre o campo intelectual sob a Ocupação. Então, eu terminei minha dissertação. Em Israel é muito comum se fazer o doutorado no exterior. Este é, sobremaneira, o percurso de excelência; como frequentemente acontece nos pequenos países relativamente dominados, faz-se a tese de doutorado no exterior. Eu já havia acordado com Even-Zohar que faria meu doutorado no exterior - que iria à França -, isso era evidente para mim. Ele me aconselhou a fazer o doutorado na França. Então, fiz meu mestrado em dois anos, lecionei..., enfim, eu já traduzia também, participei do grupo de tradução...

A.G. \& E.P. Em tudo isso, que língua era utilizada?

G.S. O hebraico. Eu escrevi meu mestrado em francês, porque Even-Zohar lia 
trinta línguas e, evidentemente, falava o francês; e fiz um grande resumo de 50 páginas em hebraico. Mas todo o meu curso foi em hebraico, eu lecionava em hebraico e havia feito curso em inglês.

A.G. \& E.P. Quantas línguas você falava nessa época?

G.S. Eu falava mais línguas do que hoje em dia, lia em francês, inglês, hebraico. Eu havia feito curso de alemão porque precisava de uma segunda língua estrangeira no BA. Fiz até cursos particulares, pois eu queria me aprofundar em alemão. Líamos Kafka no original, com um professor. Não era pelas notas na universidade, eu tinha boas notas, era somente porque eu queria me aprofundar em línguas. E para o mestrado, faltava-me ainda uma língua. Fiz sozinha, então, um curso de italiano. Peguei um "aprenda você mesmo" e o seguia todo sábado e domingo. No fim, como exame, Even-Zohar me fez traduzir um artigo. Traduzi do italiano um texto de Iúri Lotman sobre a biografia como gênero. Foi bem interessante.

A.G. \& E.P. Mas, além de você, entre os colegas de mestrado, e para além do seu orientador de mestrado, como os outros viam, por exemplo, os trabalhos de Pierre Bourdieu?

G.S. No departamento, havia o polo de narratologia, de que gostava menos, era voltado mais para a análise de textos propriamente. Nele, havia a "Escola de Tel Aviv" que se fundava sobre a tradição narratológica, sobretudo anglo-americana, mas havia também análises sobre o discurso indireto livre. É uma escola muito reconhecida e Even-Zohar tinha sua própria teoria - a teoria do polissistema -, reconhecida mundialmente. Hoje em dia ainda há especialistas em polissistema em todo o mundo. Ele é a referência sobre isso. E também é o criador dos "Translations Studies". Ele constituiu os "Translations Studies" com o belga José Lambert e seu aluno Gideon Toury como um domínio à parte. No quadro da "teoria do polissistema" ele trabalhava com a literatura israelense, interessando-se, por exemplo, pelas traduções em hebraico (que constituem quase um corpus nessa língua), as mediações tais como a da literatura francesa, que foi importada por meio do russo, enfim, todas essas questões que foram trabalhadas desde os anos 1980. Um dos cursos que eu segui foi sobre normas de tradução. Fui formada nesse meio. Havia cursos em que se ensinava Bourdieu, sobretudo sobre o conceito de campo. Os artigos eram extraídos de Questões de sociologia e versavam sobre o campo literário. Havia um sobre o mercado linguístico; um artigo sobre algumas propriedades do campo; outro, sobre a censura... Era um pouco a nossa bíblia. Todos os estudantes que seguiam Even-Zohar trabalhavam sobre polissistema e liam Bourdieu. De modo geral, era nosso quadro teórico. Então aplicamos tudo isso à literatura, com esse paradigma. Mas não éramos senhores do método sociológico. Trabalhávamos o texto. Não sabíamos fazer entrevistas, não conhecíamos outros métodos. 
A.G. \& E.P. Você ainda não tinha trabalhado com estatística até então?

G.S. Eu não sabia absolutamente nada de estatística. Mesmo o trabalho de arquivos sobre a imprensa, para mim, era completamente novo: ir à Biblioteca Nacional, retirar os dossiês, consultar os microfilmes. Eu nunca tinha feito isso antes, sempre trabalhei com livros, com textos, não era, de modo algum, uma historiadora, não tinha nenhuma formação em história. Enfim, eu continuo não tendo, mas não tive formação em história, nem em sociologia, antes do doutorado.

\section{A.G. \& E.P. E chegando à França?}

G.S. Eu não deveria dizer isso, mas, na verdade, no momento de me inscrever no doutorado, me dei conta de que a única pessoa que eu conhecia na França era Bourdieu, porque ele gentilmente havia me recebido. Mas, de todo modo, eu me coloquei essa questão sobre a sociologia, pois implicava, para mim, uma mudança de disciplina. Não era de forma alguma evidente inscrever-me em sociologia. Para além de Bourdieu, eu não conhecia nada de sociologia. Eu tinha lido A distinção, obra que me fascinou, que foi uma verdadeira revelação. É verdade que foi uma revelação quando eu a li, mas era, ao mesmo tempo, uma conversão disciplinar que precisaria ser feita. Então foi isso: eu redigi um projeto de doutorado sobre a recomposição do campo intelectual francês à época da Liberação. Era também um pouco a continuidade do diálogo com Shlomo Sand. Eu era sua assistente e ele era o mais historiador dos intelectuais, então ele me introduziu à história dos intelectuais à moda francesa.

A.G. \& E.P. Perdão, de quem se trata?

G.S. Shlomo Sand, que escreveu o livro Como o povo judeu foi inventado. Atualmente ele é uma grande estrela internacional, mas na época ele era conhecido aqui na França pelo seu trabalho sobre a solidariedade. Ele fez sua tese sob a direção de Jacques Julliard na École des Hautes Études en Sciences Sociales (EHESS). É israelense, mas havia feito seus estudos aqui, na França. Então ele me introduziu a tudo que dizia respeito à história dos intelectuais, que Even-Zohar absolutamente não conhecia. Foi ele, por exemplo, que me fez ler Christophe Charle, porque Even-Zohar não o conhecia completamente, conhecia por meio do Bourdieu. Sand me fez ler, creio, Anna Boschetti.

A.G. \& E.P. A autora de Sartre e os "tempos modernos"?

G.S. Exatamente. Então eu peguei tudo que conheci por meio dele e escrevi esse projeto sobre a recomposição do campo intelectual durante a Liberação. E o enviei a Bourdieu, que me aceitou no doutorado; mas ele me disse: "é preciso fazer um DEA" [Diplôme d'Études Approfondies, que antecedeu o mestrado na França]. Normalmente, com um mestrado em Israel, eu poderia me inscrever diretamente no doutorado, mas, como mudei de disciplina, deveria 
refazer o mestrado. Hoje em dia faço isso sistematicamente com meus alunos, eu os faço refazer o mestrado.

A.G. Estou muito contente de ouvir você dizer isto, porque a cada vez que é preciso inscrever estudantes estrangeiros, este dilema se coloca aqui na EHESS. Para as pessoas que vêm de outro país - que não a França, onde há uma grande expectativa do uso culto da língua e da tradição nacional -, se a primeira experiência de redação é a tese de doutorado, os problemas são muito mais violentos do que se, antes, se fizer um mestrado.

G.S. Você está certo. Bourdieu tinha razão, pois havia também uma mudança de disciplina. Eu fui formada em termos metodológicos durante o DEA. Estudei estatística, fizemos um curso com Salah Bouhedja, e aprendi a fazer Análise de Correspondência Múltipla (ACM), aprendi a fazer entrevistas, a conhecer métodos de amostragem, e assim por diante.

A.G. Salah Bouhedja, é bom explicar, era o responsável por todas as análises de correspondência nessa época, no Centre de Sociologie Européenne (CSE), uma das novidades metodológicas centrais utilizadas por Bourdieu, particularmente em A distinção.

G.S. Perfeitamente. Meu professor Itamar Even-Zohar, que já tinha vindo à Fondation de la Maison des Sciences de l'Homme (FMSH), era muito amigo de Salah. Ele me apresentou a Salah e nos tornamos amigos enquanto eu era estudante. E é por isso também que, quando eu entrei no CNRS, e que não havia escritório para me instalar (a direção do Centro não encontrou um escritório para mim), Salah disse: "eu a acolho no meu escritório".

A.G. O que era uma consideração enorme, porque Salah, em regra geral, não era de acolher ninguém a seu lado.

G.S. É verdade! Ele tinha adorado Itamar porque Itamar se interessava por informática há muito tempo, trabalhava muito sobre Internet e tudo o mais. Lá, nós utilizávamos o correio eletrônico já nos anos 1990. E ele vinha conversar com Salah sobre questões de informática, e depois um simpatizou com o outro. Para mim, Salah era uma porta de entrada extraordinária no CNRS. Depois, eu encontrei Francine Muel - claro, foi um grande encontro, que contou muito em meu percurso - e Victor Karady.

A.G. \& E.P. Quando foi que você chegou ao CNRS?

G.S. Cheguei em setembro de 1990. Fiz meu DEA, nós nos encontramos, todo um bando se constituiu nesse momento, pessoas que conquistaram cargos de pesquisador hoje em dia. Era engraçado, porque fiz um projeto sobre a Liberação e Bourdieu não parava de me dizer: "você não compreenderá nada da Liberação se não trabalhar com a Ocupação”. E eu não queria trabalhar com a Ocupação. 
A.G. Posso contar qual é a minha primeira recordação de sua presença no CNRS? Marie-France e eu viemos para a França em 1992, para um segundo pós-doutorado. Assim nós frequentamos o mesmo seminário na EHESS que você, Odile Henry, Grazia Scarffo e muitos outros.

G.S. Sim, o seminário anual de Bourdieu na EHESS.

A.G. E minha primeira recordação é de você dizendo: "tenho um objeto de pesquisa terrível, porque quero estudar como as pessoas vão buscar resolver querelas literárias através da política”.

G.S. Não me lembro. Mas por que eu disse isso?

A.G. Era uma rodada na qual cada um deveria apresentar o que estava fazendo. Dizendo isso, você explicitava que era, ao mesmo tempo, um objeto muito sedutor e um grande desafio. Para Marie-France e para mim, efetivamente, ele nos parecia um grande desafio. Ao mesmo tempo - o que é confirmado pelo seu livro - pensávamos que somente alguém que viveu muito tempo no exterior, e que tinha certa distância com relação à França, poderia enfrentar esse objeto.

G.S. Eu nunca tinha pensado nisso. É estranho, porque, para mim, o objeto é distante por outra razão. Eu vinha da teoria literária e da filosofia, e não da história; não conhecia essa história, de fato. Não conhecia muito bem os autores. Quero dizer, não eram lidos. E talvez eu tenha lido um pouco de Mauriac, mas não estou certa. Aragon, eu não o tinha lido. Tinha lido Sartre, isto sim! Muito. E a literatura para mim era muito importante. Mas interessar-me pela vida dos escritores me era completamente estranho. É nesse sentido que esse objeto era distante para mim. Ao mesmo tempo, tinha a questão da Ocupação, que não dizia respeito diretamente à minha história familiar, porque meus pais imigraram para a França, no entanto eles foram de alguma maneira envolvidos. Por isto, dizer que é um objeto distante é e não é verdade ao mesmo tempo.

A.G. \& E.P. Claro, mas você vem do lado das vítimas da potência Ocupante, não é assim?

G.S. Sim, mas não diretamente.

A.G. \& E.P. Não diretamente vítimas, mas mesmo assim...

G.S. Sim, é isso. E eu me lembro que Francine Muel me falou, em um momento, de minha relação com esse objeto. Acho que é a razão pela qual eu não queria trabalhar sobre a Ocupação, mas, sim, sobre a Liberação. Agora, evidentemente, a Liberação não era estranha, pois era a recomposição da imagem de si para a França e tudo que gira em torno disso. Mas eu me lembro, escrevi isso no meu DEA, é interessante. Eu tinha em mente o que queria fazer. Tinha lido o livro de Herbert R. Lottman - não o mesmo de agora, não Iúri 
Lotman, mas Herbert, jornalista -, que fez uma boa história dos intelectuais, especialmente sobre esse período, e me interessei muito pelo Comitê Nacional dos Escritores. Eu não sabia por que, mas me interessava muito essa instância durante a Liberação. E Bourdieu me incentivou a trabalhar sobre a Academia Francesa e a Academia Goncourt. Eu nunca teria tido essa ideia sozinha e ninguém tinha trabalhado a esse respeito no período da Ocupação. Não era, absolutamente, tratada na história dos intelectuais, que era muito "individualista", centrada nos indivíduos. Eu acho que ele teve uma ideia de gênio, uma intuição muito forte, mesmo que no momento do DEA ele tenha dito: "é preciso parar, terminar com o trabalho sobre as instituições". Eu tinha construído tudo em torno das instituições da vida literária. Eu me apoiava em Alain Viala. Tentei capturar o campo no momento de sua desarticulação, por meio da evolução das instituições que deveriam garantir a autonomia do campo, porém, na verdade, foi por meio delas que se introduziu a heteronomia. Foi assim que eu as reconstruí. E, no mesmo momento, a necessidade de criar uma nova instância clandestina, o Comitê Nacional dos Escritores, para reconquistar a autonomia perdida. Bourdieu estava muito contente e me disse: "Bom, mas as instituições são listas de nomes, não se pode fetichizá-las". Em seguida, eu trabalhei, repensei e me disse: "as instituições existem. É preciso trabalhá-las em diferentes níveis: em um nível como instância enquanto tal, como um agente coletivo, enquanto agente dentro do campo, porque elas têm uma imagem, produzem uma imagem, elas também produzem sanções, concedem prêmios. A instituição atua como um agente, mas também como um grupo de indivíduos heterogêneos que lutam pela boa definição da instituição. E, evidentemente, esse terceiro nível se passa em situações particulares, como em conjunturas de crise como essa, na qual há novas limitações que pesam sobre essa instituição e ela deve justificar sua existência, ou redefini-la". Isso foi o que eu pensei em relação à teoria dos campos. Não está inscrito na teoria do campo, eu a trabalhei desta maneira, articulando-a com a questão da autonomia. De todo modo, escutei Bourdieu e finalmente trabalhei sobre a Ocupação, detive-me durante 15 anos nesse assunto. Mas a tese eu a fiz em três anos, graças a Bourdieu.

A.G. \& E.P. E como você acredita que Bourdieu via a importância desse objeto? G.S. Eu me lembro, sem dúvida, desse mesmo seminário no qual se falou de tudo isso. Lembro de Bourdieu dizendo - em seminário no qual havia uma apresentação rápida de cada um: “ah, sim, esse é um objeto importante porque aqui, nos corredores da EHESS, as pessoas poderiam se matar em situações como essas". Eu me lembro disso porque fiquei marcada por sua afirmação. Devo dizer que, quando houve uma série de ataques contra Bourdieu, no momento de seu engajamento, em 1995, eu já tinha terminado minha tese, mas estava escrevendo o meu livro, trabalhando sobre as querelas dos 
maus mestres em 1940 - momento no qual se estigmatiza Gide, Mauriac, acusando-os de terem sidos maus mestres -, que a derrota foi culpa deles, causada por irresponsabilidade deles. ${ }^{6}$

A.G. \& E.P. Esse tema é tratado em A guerra dos escritores.

G.S. Isso mesmo. Não foi tratado dessa maneira na tese, mas eu estava trabalhando nele naquele momento para o livro. Para mim uma imagem esbarrou na outra, quer dizer, os ataques contra Bourdieu lembraram-me exatamente dessa querela dos maus mestres. Querelas de rivalidade que tomam uma proporção política, ou seja, às quais se dá um tratamento político para universalizá-las no mesmo momento. Eu vivi de maneira muito violenta esses ataques porque, para mim, esse mecanismo ecoava em circunstâncias nas quais as pessoas eram ameaçadas; era uma maneira de denunciá-las politicamente com todas as consequências dessas acusações. Eu acho que, para ele, era um assunto muito importante, claramente. É por esse motivo que ele me incentivou a trabalhar sobre a Ocupação. Ele tinha razão em dizer que eu não compreenderia nada da Liberação se não trabalhasse sobre a Ocupação. Para mim era demais. Acho que eu me sentia, em função do que vocês disseram, muito envolvida com uma das partes para trabalhar tal tema. Certo é que eu não me sentia suficientemente distanciada.

A.G. Se me permite, vou tentar explicitar outro ponto de vista sobre o alcance de sua pesquisa. Acredito que foi a primeira vez que alguém no CSE trabalhou sobre a heteronomia de um campo que já se tinha autonomizado. É verdade que Bourdieu nunca adotou o princípio evolucionista, segundo o qual, uma vez que a autonomização se produziu, ela não poderia jamais voltar atrás. No entanto, eu nunca vi um trabalho tendo por objeto o recuo da autonomização de um campo, e a sua pesquisa era uma ocasião muito boa para refletir exatamente sobre um assunto tão difícil de pensar. Quer dizer, como a política pesa sobre o mundo literário; ela não pode pesar como as autoridades políticas gostariam. Para aqueles que vinham de um país autoritário, era o meu caso e o de Marie-France, era ainda mais interessante, porque você problematizava como a autonomização do campo pode existir, e o que pesava em literatura durante um regime autoritário. Você dispunha quase de uma experimentação completa. O momento da Ocupação conduz à heteronomia da atividade literária, depois o estudo do Comitê Nacional dos Escritores esclarece o retorno à autonomia. Havia uma novidade propriamente teórica fundada sobre um estudo bem empírico.

G.S. Sim, é verdade. No coração está a problemática teórica da autonomia; o que quer dizer e através de que meios ela se traduz. Como pensá-la e como pensar também a heteronomia, porque ela me interessava talvez mais do que a autonomia. Isso estava no centro de minha postura. E continua, eu nunca 
parei de trabalhar sobre a questão da autonomia, não sei por que, mas é o que me atrai. Eu traduzi um artigo para o hebraico que muito me marcou, fazia parte de uma antologia que Even-Zohar queria fazer, mas nunca foi publicado. Nós passamos um tempo a retrabalhá-lo, ele inventava palavras porque, por exemplo, "distinção" não existia em hebraico, nem "nobreza". Não o terminávamos nunca. Um dos textos de Bourdieu que mais me marcou foi "O mercado de bens simbólicos". Não é um texto de que todo mundo fala espontaneamente. É um velho artigo de 1971 no qual justamente a questão das forças e limitações que pesam sobre a literatura, o papel das instituições, é central. E isto é algo que desapareceu dos artigos mais teóricos sobre o campo. Bourdieu nem mesmo utiliza o conceito de campo. Ele fala de mercado, mercado de bens simbólicos, de um momento de autonomização no começo do século XIX. É um artigo que me estruturou profundamente, muitos dos meus trabalhos se referem implicitamente a ele, sem dúvida mais que a outras coisas. As regras da arte ainda não tinha sido publicado quando comecei, foi editado em 1992.

A.G. \& E.P. Mas já havia sido publicado "A invenção da vida de artista", não? G.S. Sim, no entanto, era um dos raros artigos que eu não tinha lido. Já tinha lido, eu lhes disse, todos os artigos de Questões de Sociologia e tudo o que ele tinha escrito sobre campo literário.

A.G. \& E.P. Até agora nós falamos de seu encontro com Bourdieu e, como, ao encontrá-lo, você foi confrontada com seu próprio trajeto e o que se abria para ele naquele momento. Como você vê o encadeamento das interrogações de Bourdieu e, do seu ponto de vista, quais são as suas maiores contribuições teóricas e metodológicas?

G.S. A questão é como eu o percebia naquele momento, ou quais são hoje em dia, para mim, as contribuições de Bourdieu? Não é exatamente a mesma pergunta, porque eu trabalhei bastante este problema a partir de sua trajetória. Assim, hoje, tenho uma visão diferente daquela que tinha.

A.G. \& E.P. Podemos começar da sua visão atual.

G.S. Então, vocês querem dizer, sua contribuição sociológica, de uma maneira geral, ou sobre a literatura?

A.G. \& E.P. Como estudante orientada por ele, existia essa relação direta, individual. Até aqui nós tratamos da sua relação individual e o objeto que você construiu, mas se você situasse esse objeto no andamento das pesquisas de Bourdieu, como o faria? Nesse momento, ele estava no Collège de France há mais de uma década, um sinal importante de sua consagração.

G.S. Sim, eu fiz o curso sobre o Estado ministrado no Collège na época. De 1990 a 1992, fiz todos os cursos sobre Estado. O que eu compreendi estudan- 
do, agora, o seu percurso, é que este foi o tempo forte de sua internacionalização. Eu não percebia isso à época. E, no entanto, poderia ter percebido, porque ele enviou a Even-Zohar as três conferências que fez no Japão e me pediram para traduzi-las para o inglês para a Poetics Today.

A.G. \& E.P. Aquelas que estão publicadas em Razão prática?

G.S. Exatamente. Eu as traduzi para a Poetics Today e depois o texto foi revisto por Brian McHale, porque meu inglês não era suficientemente bom; mesmo assim, só existe essa versão em inglês. Ele foi convidado a ir ao Japão em 1988, depois da publicação de A distinção pela Harvard University Press, portanto, em inglês, o que aumentou muito sua recepção nos Estados Unidos e, ao mesmo tempo, no mundo. Há uma recepção internacional de Bourdieu na Alemanha, na Itália, muito cedo, relacionada às questões sobre arte; no Brasil também, via Sergio Miceli, que fez uma antologia sobre o poder simbólico. É um recorte muito original, ninguém havia feito isso.

A.G. \& E.P. Essa coletânea chama-se Economia das trocas simbólicas. Um dos artigos é este, sobre os mercados dos bens simbólicos que você mencionou há pouco. Mas podemos retomar a questão da recepção internacional.

G.S. Certo, eu posso dizer mais alguma coisa sobre sua trajetória teórica. É um momento de internacionalização dela que, ao mesmo tempo, teve um efeito de retorno sobre sua teoria. Trabalhei isto no artigo sobre as leituras de Pierre Bourdieu que entreguei a Gérard Maugé e que deve sair nas edições Silepse. Ele começa a se interrogar sobre a possibilidade de transposição de seus conceitos para outros lugares que não a França, por volta de 1989. Portanto, ele refletiu sobre a noção de "capital burocrático" que se tornou, em seguida, "capital político" para adaptá-lo aos países do Leste da Europa. Refletiu sobre a noção de "distinção". O que significa "distinção" no Japão? Como podemos ou não podemos transportar os conceitos e as noções para outros países? O debate sobre A distinção nos Estados Unidos indagava: "será que se pode aplicar esse conceito neste país?". Tentou-se constituir critérios empíricos para objetivar o "capital cultural", mas de fato não se chegou a encontrar equivalentes. Então, começou-se a colocar em questão o modelo conceitual. Isto já tinha acontecido na Alemanha. Colocou-se em questão o modelo em bloco, dizendo que não se aplicava ao país, em vez de se perguntar sobre os critérios de diferenciação específicos ao país. Assim, Bourdieu começou a desenvolver uma reflexão metodológica comparatista. Esse é também o momento em que ele se engaja em projetos europeus no início dos anos 1990. É desse período A miséria do mundo; eu ouvi quando ele falava sobre essas coisas. Participei um pouco da Líber [Revue Européenne des Livres] e da Actes de la Recherche en Sciences Sociales, após a tese. Não estava realmente presente nos projetos coletivos, mas observei-os de longe e depois reconstruí o todo. Eu 
sei, agora, que naquela época ele começou a se engajar também nas questões europeias. E também é o momento no qual se internacionaliza seu engajamento político. Nota-se a mudança, mas a mudança política é mais tardia. Eu concedi entrevistas sobre os dez anos de sua morte e me lembro de que um dos jornalistas questionou-me se eu tinha ficado surpresa com o engajamento político de Bourdieu em 1995. Eu me dizia: "não, não me lembro de ficar surpresa". Eu pensava, pensava... E depois, de repente, à noite, a lembrança me veio. Era a greve! Estávamos todos mobilizados, estávamos todos na rua, nas manifestações! Era absolutamente natural o seu engajamento. Para nós, era coerente e, de certa maneira, não poderia ter sido de outro modo. Mas foi engraçado porque eu tive uma espécie de "black-out". O movimento de 1995 foi uma experiência extraordinária, inesquecível.

A.G. \& E.P. Ao mesmo tempo, o fato de ele utilizar sua autoridade contra uma parte dos intelectuais que diziam que manter as conquistas sociais era coisa de dinossauros...

G.S. Sim, o conservadorismo e a inversão das categorias da história política tradicional. Bom, eu tinha boas ferramentas para decodificar tudo isso, principalmente sobre os intelectuais. Foi aí que começaram os ataques contra Bourdieu. Muito violentos. E eu os decodifiquei.

A.G. \& E.P. Houve O "dezembro" dos intelectuais franceses, de 1997.

G.S. Sim, mas os ataques a Bourdieu são de 1995, de uma violência incrível. E eu os lia à luz das querelas de maus mestres sobre a Ocupação e os decodifiquei assim, como um ajuste de contas e como ataques de pessoas que não tinham os meios de combater Bourdieu intelectualmente, cientificamente. Então, eles tentaram desacreditá-lo, tentaram desvalorizar sua teoria falando de seu engajamento político, porque não tinham meios de combatê-lo com armas intelectuais. Era muito violento e, ao mesmo tempo, era de uma grande efervescência. É o momento no qual foi criada a editora Raisons d'Agir. Participei dela no começo, mas não fiquei porque não era meu modo de engajamento, ficava mais à vontade nas manifestações. Tudo aconteceu ao mesmo tempo, de uma única vez.

Gostaria de voltar a um ponto anterior. As regras da arte não tinha sido publicado quando redigi minha tese, então eu não tinha esse corpus de texto como referência. Encontrei o plano nos textos de Bourdieu, de 1970, sobre os intelectuais. Em relação aos parâmetros, eu tinha construído variáveis na tese, mas mesmo frente à análise quantitativa, Bourdieu estava cético, ele dizia: "não se pode fazer quantitativo sobre os escritores, porque eles possuem grandezas diferentes, tamanhos diferentes e isso não se pode restituir na análise". E, na verdade, ele ficou surpreso com o resultado de minhas análises quantitativas. Ficou realmente contente com as Análises de Correspondência Múl- 
tipla, porque antes ele havia me dito:" nós não lhe ensinamos nada, mas eu vou lhe ajudar". No dia seguinte de minha defesa de tese ele me telefonou para dizer: "agora é preciso fazer análise de correspondência", porque eu não as havia apresentado na tese.

A.G. \& E.P. O período de 1993-1995 foi de forte ataque contra Bourdieu e, ao mesmo tempo, ele recebeu a medalha de ouro do CNRS. Foi mais ou menos na mesma época em que você recebeu a sua, não?

G.S. Não, não foi no mesmo momento. Sua medalha foi no momento de meu recrutamento ao CNRS. Ele foi premiado em 1993, e eu fui recrutada em 1995. Foi a primeira medalha de ouro em Ciências Sociais, eu acho. ${ }^{7}$

A.G. \& E.P. Esses prêmios mostravam que sua pesquisa era considerada como um trabalho inovador. Nessa época, Bourdieu acumulou os sinais de notoriedade científica como membro do Collège de France, medalha de ouro do CNRS e outros.

G.S. Minha medalha de bronze foi mais tarde. ${ }^{8}$ No entanto, meu recrutamento para o CNRS, claramente está ligado ao seu prêmio. Porque até aquele momento, as pessoas que trabalhavam com Bourdieu não eram recrutadas facilmente pelo CNRS, porque o Centro era dominado por outras correntes. Mas o que ocorreu foi que Odile Henry descobriu, uma semana antes do concurso, que ela não poderia mais se candidatar, pois havia diminuído o limite de idade. Foi por isso que ela não se apresentou ao CNRS em CR1 [chargé de recherche de $1^{\text {ère }}$ classe], eu me apresentei em CR2 [chargé de recherche de $2^{\text {ème }}$ classe] e passei. Se não tivesse havido diminuição do limite de idade, eu não me apresentaria naquele ano. Era um ano no qual havia mais postos e Bourdieu, efetivamente, disse, no momento da cerimônia da medalha de ouro, no final de seu discurso, com todas as letras, que ele queria postos para as pessoas que trabalhavam com ele. Então ele fez uma carta de recomendação muito elogiosa, e foi tudo. No final, fui classificada em primeiro lugar.

A.G. \& E.P. É um bom indício de como a força científica de Bourdieu não provinha de forças institucionais.

G.S. Ah, sim, isto é certo. Os mecanismos, eu os compreendi bem. E para mim foi uma sorte extraordinária entrar no CNRS, porque assim a questão de retornar a Israel não se colocou mais.

A.G. \& E.P. Passemos para o outro conjunto de questões, a propósito dos destinos dos trabalhos de Pierre Bourdieu. Você fez muitas viagens, especialmente nesses últimos anos, para dar cursos e conferências, o que implicou longas estadias nos Estados Unidos, em outros países da Europa, na América Latina, na Ásia. Você publicou numerosos artigos sobre tradução, inclusive 
sobre a tradução das obras de Pierre Bourdieu. Como você considera, portanto, esse efeito internacional da obra de Bourdieu, no caso, fora da França? G.S. O que eu posso dizer, o que me parece o mais importante a esse respeito, é o fato de ser uma obra que realmente funcionou como um programa de pesquisas no exterior. Quer dizer, as análises realizadas com Mauricio Bustamante mostram que houve diferentes fases da recepção dos livros de Bourdieu. Há a fase na qual a recepção é mais fragmentada, até meados dos anos 1980, em que a difusão é feita por especialidade. Há a recepção do sociólogo da educação, do antropólogo, quer dizer, a recepção pela antropologia na ocasião da publicação de O senso prático, e depois há, igualmente, aquela da sociologia da cultura. Em diferentes países são grupos diferentes que discutem, mas não necessariamente entre eles; como dizia Craig Calhoum, eles não faziam parte da mesma conversa. Rogers Brubacker propôs uma leitura, em 1985, destacando a relação com Max Weber. Identificava-se muito Bourdieu com o marxismo e Brubacker quebrou isso em um artigo da Theory and Society, destacando a importância não somente de Durkheim e Marx como fontes, mas também de Weber. De repente, isso muda completamente o modo de percepção de Bourdieu. Craig Calhoun descobriu Bourdieu na Inglaterra, já nos fim dos anos 1970, e o introduziu em Chicago. Os workshops que foram organizados por volta de 1986, 1987, em Chicago, vão alargar os círculos de recepção. Depois Loïc Wacquant chega aos Estados Unidos e introduz Bourdieu sob outros aspectos. Em seguida são formados grupos de pessoas mais diretamente ligadas à obra em seu conjunto. Teve a recepção de A distinção, que ajudou a constituir o domínio da sociologia da cultura nos Estados Unidos. Antes, esse domínio não existia enquanto tal. Havia, mais especificamente, a sociologia da arte. Vera Zolberg, e seu marido Henry, descobriram muito cedo a obra de Bourdieu, nos anos 1960. Eles o introduziram e desenvolveram a sociologia da arte a partir dos trabalhos sobre museus e outros trabalhos da mesma época. Contudo, a sociologia da cultura enquanto práticas culturais não existia. A publicação de A distinção vai estruturar esse domínio de pesquisa e, ao mesmo tempo, vai criar uma espécie de domínio de pesquisa muito positivista sobre os indicadores de capital cultural. Teve a revista Poetics que introduziu a teoria do campo literário e que também deu lugar a uma apropriação muito positivista. No início dos anos 1990, há o livro coletivo dirigido por Craig Calhoun, Edward Lipuma e Moishe Postone, Bourdieu: critical perspectives, que destaca a dimensão teórica, porque é preciso compreender que nos Estados Unidos há uma separação entre teoria e empiria muito forte, e Bourdieu não entrava em nenhuma etiqueta simplista. Não era a teoria pura: ele tinha muita empiria para ser teórico e muita teoria para ser empírico. De certa maneira, ele não era suficientemente positivista no sentido americano. Então, eles fornecem uma leitura teórica de Bourdieu. De toda forma, atualmente eles se arrependem, porque acham que ficou teórica 
demais. O conceito de capital já era bem difundido, particularmente o de "capital cultural". É esse conceito que aparece com maior frequência nas revistas de ciência sociais americanas desse período. Há uma pesquisa feita na época por dois pesquisadores, Jeffrey Sallaz e Jane Zavisca, sublinhando que o conceito de "capital cultural" é muito difundido. O conceito de "habitus" se difundiu via trabalhos de antropologia. Por outro lado, o conceito de "campo", até os anos 1990, não aparece. Eu me lembro de que quando nós partimos com Bourdieu - Frédéric Lebaron e eu - para o colóquio de Colônia, na Alemanha, a respeito das Análises de Correspondências Múltiplas, com Johan Heilbron e Brigitte Le Roux também, Frédéric e eu fomos os únicos, em todo o colóquio, a apresentar alguma coisa sobre o conceito de "campo". Todo mundo tinha trabalhado as Análises de Correspondências Múltiplas a partir de A distinção, isso em 1996 ou 1997, talvez. O conceito de "campo" teve uma recepção internacional mais tardia.

A.G. \& E.P. Mas na Alemanha a recepção é um pouco diferente dessa periodização...

G.S. Completamente, porque há uma recepção do conceito de "campo" muito mais cedo, por Joseph Jurt, mas nos estudos literários. Como tem em Israel o conceito de "campo", mas é igualmente pelos estudos literários. Na sociologia, de modo algum. O conceito de "campo" entra tardiamente nas referências das principais revistas. Claro, teve a Theory and Society e Poetics, mas Poetics era restrita aos estudos literários no início, e ainda continua, eles são principalmente literários.

O livro de Calhoun, Lipuma e Postone apresenta a teoria de Bourdieu como teoria e, de repente, Bourdieu torna-se um grande nome - como Foucault, Derrida, Barthes - até mesmo fora da sociologia, mesmo que sua recepção não esteja ligada à French Theory de maneira direta. É menos frequente em sociologia, mas pode-se ver que a citação ritual de Bourdieu torna-se corrente: pessoas que o leram apenas de segunda mão ou que têm ideias preconcebidas, pessoas que não o leram seriamente. Por outro lado, é possível ver também como Bourdieu foi apropriado por verdadeiros programas de pesquisa. Michèle Lamont, que trabalhou de perto com a teoria de Bourdieu e fez uma interpretação pessoal; Loïc Wacquant, que formou muita gente em Berkeley; Calhoun é muito central também nessa recepção, mais central, com certeza, do que Lamont. Atualmente, há uma nova geração, não é propriamente uma nova geração, mas pessoas que descobriram Bourdieu cada vez mais, nos Estados Unidos e no mundo também, e que se firmaram. Além dos Estados Unidos, vi que na Alemanha por um longo período havia somente Joseph Jurt, romanista que se interessava por Bourdieu. Há, em torno de Norbert Wolf e Marcus Joch, uma nova geração de especialistas em literatura alemã que começaram a se interessar pela teoria do "campo". Aconteceu também na Itália, mas de ma- 
neira mais restrita e, infelizmente, foi uma tragédia, porque o jovem colega que fazia isso, que tinha descoberto Bourdieu, suicidou-se muito jovem. Ele não chegou ao final de seu projeto. Foi muito dramático. Nós o encontramos na rede estabelecida pelo projeto europeu Espace pour les Sciences Sociales Européen (ESSE). Atualmente, há pessoas que se aproximam cada vez mais de Anna Boschetti para desenvolver análises inspiradas em Bourdieu, incluindo estudos sobre a Itália. Em Israel a recepção vem de longa data.

A.G. \& E.P. Você havia falado da Índia.

G.S. Na Índia, houve o colóquio organizado por Roland Lardinois e Meenakshi Thapan. No entanto, os indianos são muito acadêmicos. Ou têm um discurso muito geral, ou trabalhos empíricos que não se inspiram muito em Bourdieu. Não encontrei na Índia interlocutores que realmente trabalhassem com o quadro teórico de Bourdieu, contrariamente ao Japão, onde há uma recepção antiga. O caso do Japão é muito interessante porque Arusho Kato, que é um grande especialista em Bourdieu e supervisionou todas as traduções - é um literato, um romanista também -, descobriu Bourdieu pelo livro de Anna Boschetti sobre Sartre, porque ele era sartreano. Ao ler o prefácio no qual Anna resume a teoria do "campo" de Bourdieu, ele disse: "mas quem é esse sociólogo? Quem é esse pensador?"

A.G. \& E.P. Você acabou de receber uma colega chinesa que traduziu A distinção na China, agora.

G.S. Ah, sim. Olhando os dados com Mauricio Bustamante, em 2008, constatamos que já existiam 17 traduções de Bourdieu para o chinês. Ela fez sua quinta tradução, cujo título não olhei, mas é recente. É uma especialista em literatura francesa, farei uma entrevista com ela na próxima semana. No Japão a recepção é mais antiga, Bourdieu foi convidado para pronunciar conferências em 1989, e essa viagem abriu a recepção de sua obra.

A.G. \& E.P. A sociologia da literatura foi importante para muita gente.

G.S. Sim, é importante para a recepção internacional de Bourdieu. Eu penso também na Bélgica, onde não há tradução, mas há um grupo composto por Jacques Dubois e pessoas do círculo de Liège. E agora há uma nova geração que trabalha com a teoria do campo, no domínio da sociologia da literatura, formada por egressos de estudos literários. Isso ocorreu na Suécia, sobretudo na ciência da educação.

A.G. \& E.P. Você pôde verificar se, nessa recepção internacional recente, houve objetos de pesquisa que Bourdieu não desenvolveu, mas que foram retomados por seus colaboradores, a exemplo de Abdelmalek Sayad, que estendeu a reflexão sobre a imigração argelina para a França, dando continuidade aos 
trabalhos precedentes sobre a Argélia?

G.S. Havia Joseph Jurt na Alemanha, que desenvolvia um projeto de tradução com Bourdieu, o qual continuamos no Laboratório. Houve o projeto europeu em torno de Franz Schulteis, mas a recepção não chega a todos os domínios. Houve poucas colaborações diretas com Bourdieu. Em sociologia da ciência, não havia muita coisa, isso é interessante também. Apesar do livro de Bourdieu, Science de la science et réflexivité, ele não teve colaborações posteriores, ao menos que eu saiba. Isso é desenhado atualmente com a renovação da sociologia dos intelectuais nos Estados Unidos sobre a história das ciências sociais, a "new sociology of knowledge", mas Bourdieu ficou um pouco ocultado. A sociologia dos intelectuais é um domínio que se desenvolve na França, mas que não se desenvolveu da mesma forma em outros lugares. Houve recentemente uma retomada nos Estados Unidos, mas mesmo assim não há equivalência. Nós criamos uma rede temática na Associação Francesa de Sociologia e não há uma igual na American Sociological Association nos Estados Unidos. Há alguma coisa na sociologia da educação, na sociologia do mundo universitário.

A.G. \& E.P. Qual é o lugar que você atribui às atividades editoriais de Bourdieu? Bourdieu produzia artigos e livros, mas também editava a coleção Le sens commun na editora Minuit e Actes de la Recherche em Sciences Sociales. Que lugar atribuir às estratégias propriamente editoriais na construção de sua rede de pesquisa internacional? ${ }^{9}$

G.S. Bourdieu mostrou como isso pode ser central, quer dizer, fazer verdadeira edição, fazer uma verdadeira revista, mas uma revista com critérios outros que os acadêmicos. Dito de outra forma, havia critérios acadêmicos muito estritos, muito restritivos, do ponto de vista da exigência científica, mesmo se não era padronizada, regida por normas, como é o caso de hoje em dia. Mas é também uma revista que introduziu caricaturas, ilustrações, era ao mesmo tempo interdisciplinar e visava um público mais amplo que o mundo acadêmico, e isto é realmente raro, aqui, para uma revista acadêmica. E mesmo para as edições, porque ele sempre fez um trabalho editorial. As coleções que dirigiu são constituídas por livros escolhidos de uma maneira extremamente exigente. Ele traduziu Ernst Cassirer, Erwin Panofsky, publicou obras filosóficas extremamente complexas, mas ao mesmo tempo, ele as publicou em uma editora que não tinha grande distribuição, mas possuía um público que não era puramente acadêmico, pois não se tratava de editora universitária e isso coincide com o grande momento do boom das ciências sociais. Mas pela sua coleção, ele é quase um precursor. É o momento no qual as casas editoras Seuil, Gallimard criam também coleções. Então, é realmente contemporâneo da inovação editorial. É verdade que sua coleção é uma coleção de obras importadas, sobretudo feita de muitas traduções. Trouxe 
para a França todo um corpus estrangeiro que nós não conhecíamos. Ele traduziu, por exemplo, Erving Goffman, editou também um conjunto de textos de Durkheim, de Mauss, organizadas por Victor Karady, que não tinham sido editados. Ele criou, assim, um corpus da disciplina, porque a sociologia estava se constituindo enquanto disciplina acadêmica. Não se pode esquecer: a graduação em sociologia na França é de 1958, portanto é uma espécie de refundação da disciplina que havia sido extirpada pela guerra. Ao mesmo tempo em que ele era filósofo de formação, era um antropólogo, um ávido leitor, lia tudo que passava em sua frente. Eu fiz uma entrevista com ele na qual me contou muitas coisas. Tinha uma livraria, acho que era na rua Soufflot, ele passava e pegava tudo o que lhe caía nas mãos. Lia tudo, leu Schultz antes de ser traduzido. Passou um verão traduzindo Cassirer, depois Panofsky. Foi ele quem traduziu Architecture gothique et pensée scolastique.

A.G. \& E.P. E essa referência foi central na teoria de habitus.

G.S. Certamente! Era nesse período que ele formulava sua primeira teoria do habitus, no posfácio ao livro de Panofsky. A primeira ocorrência do habitus aparece no texto constitutivo da obra O baile dos celibatários, a propósito das técnicas do corpo, de Mauss. O texto que abre este livro é de 1962, e Architecture gothique et pensée scolastique é, me parece, de 1967. No posfácio ele associa as categorias de percepção e pensamento. O conceito de habitus se forma e vê-se bem que sua teoria se elabora, sobretudo, no contato com a pesquisa empírica. Esta é a força da teoria de Bourdieu. Essa constante confrontação com o real, com o mundo real, com o material empírico extremamente rico, que combinava métodos diferentes, quantitativo e qualitativo ao mesmo tempo, essa leitura inacreditável muito ampla de todas as disciplinas.

A.G. \& E.P. Você vinha do método de análise de texto e teve que se confrontar com os métodos quantitativos, ou com esse uso muito fino de métodos quantitativos e qualitativos, lado a lado. Como você vivenciou essa diversidade? G.S. A verdade é que eu descobri os métodos quantitativos no DEA. Lembro-me de quando fiz um questionário em um curso de estatística. Eu não sabia o que era um questionário. Lembro-me de que trabalhei com um colega que me explicou como eu deveria fazer e logo entendi. Eu gosto bastante do método quantitativo. Na verdade, em relação aos materiais muito textuais, fazer quantitativo descansa minha cabeça. Foi uma experiência fazer o questionário, eu não me lembro mais de quantas questões, acho que eram 128 questões. Não era um verdadeiro questionário, era um questionário prosopográfico, um misto de questões sobre um indivíduo e de recuperação de dados presentes em diferentes arquivos. Eu construí minhas variáveis assim. Uma coisa muito me impressionou. A ideia de fazer uma contagem é algo que nunca tinha pensado. Eu li Christophe Charle e frequentei seu seminário. Ele era um modelo para 
mim, sobretudo seu estudo sobre o caso Dreyfus. Foi então que comecei a usar dado quantitativo. Bourdieu era cético quando eu dizia que usaria dado quantitativo para o campo literário. O que fiz foi introduzir variáveis que ninguém tinha utilizado antes: sobre os editores, variáveis literárias, sobre os gêneros praticados. Existia a tese de Rémy Ponton, que era um modelo extraordinário, eu o procurei a propósito das propriedades sociais dos escritores. Ele tinha analisado as escolas, mas seu estudo não tratava dos editores, das revistas e, desse ponto de vista, existia algo novo na minha tese. É isso que dá a solidez de meu estudo porque essas variáveis objetivas - publicou ou não em uma grande revista, em tal editor - de repente restituem o "campo". É verdade que eu não pude duvidar que as pessoas que publicavam em uma revista de poesia, não publicavam na grande imprensa. Via-se nas análises de correspondência. Isso permitiu comparar as instituições entre si. É simples: o dado quantitativo permite sistematizar os dados que o espírito não permite sintetizar. Nós temos uma apreensão intuitiva. Eu trabalho muito com o quantitativo, mas nunca somente com o quantitativo. É a mesma coisa quando trabalhamos sobre tradução, trabalhamos apenas com as línguas que dominamos, sabemos o que contamos, verificamos o que contamos. Eu construí meus dados, então eu sabia tudo o que eu contava. Eu digo aos meus estudantes, o dado quantitativo não fala sozinho. Para fazê-lo falar, é preciso do qualitativo. Essa oposição entre quantitativo e qualitativo prevaleceu nos Estados Unidos, na França felizmente não é assim. É verdade que quando comecei a fazer quantitativo, era num nível muito descritivo, simplista, pois a modelação estatística e tudo o mais, não sabia fazer. Eu adorava fazer, mas não sabia como.

A.G. \& E.P. Se olhamos com vagar para os livros de Bourdieu, percebemos que os números de Actes de la Recherche frequentemente precederam a cristalização completa de alguns objetos e conceitos explicativos. Quase como se a teorização só pudesse avançar por meio de balões de ensaios, fiel à ideia de que a pesquisa se fazia pela renovação das tentativas de explicar um objeto preciso. Por meio de Actes, Bourdieu parecia romper as fronteiras entre uma pesquisa puramente individual e algo de muito mais amplo, no qual as pesquisas analisadas pareciam ser o resultado de trabalhos conduzidos em rede. Para sua recepção internacional Actes não teria sido um trunfo?

G.S. Na dimensão política, eu acho que Bourdieu fez obra de pioneiro para o domínio das ciências humanas e sociais na França. Mesmo a noção de um laboratório, no sentido que o CNRS dava a essa palavra nos anos 1950, 1960, quando retomava a noção de laboratório no sentido das ciências duras. Ele constituiu um verdadeiro laboratório: existia um chefe do laboratório, uma equipe, um trabalho coletivo, uma divisão do trabalho, cada um levava uma parte, mas se inscrevia num projeto mais vasto. E essa modalidade de divisão do trabalho era nova. Pois não é uma divisão do trabalho no sentido das 
ciências da natureza nas quais é dado ao estudante um trabalho de pipeta e depois ele vai assinar em uma lista de quinze pessoas. Quer dizer, cada um tinha um objeto seu, mas, como você disse, esse objeto toma sentido em um conjunto mais vasto no qual existiam questões comuns de pesquisa. Isso desapareceu, e quando eu entrei no Centro, já não estava mais tão presente.

A.G. \& E.P. Actes exerceu um forte efeito estruturante sobre toda a rede de pesquisadores baseados na França ou residentes no exterior, não?

G.S. Essa revista se impôs para além do Centro e ela estruturou enormemente a pesquisa, e ainda ultrapassou a disciplina. Eu trabalhei bastante, durante minha tese, com os jovens historiadores e cientistas políticos - havia mais historiadores e cientistas políticos do que sociólogos - e eu via muito bem a recepção de Bourdieu na história, em toda uma geração de historiadores, como Anne Simonin e outros que estão agora na EHESS. Mas eu vejo a recepção de Bourdieu no domínio da história dos intelectuais. Na história intelectual e na história cultural há uma forte recepção de Bourdieu, mais do que em outros domínios. Na ciência política também. Por exemplo, em nosso laboratório, hoje em dia, que é a fusão do CSE, antigo laboratório de Bourdieu, e do Centro de Pesquisa Política da Sorbonne, há um conjunto de cientistas políticos que descobriram Bourdieu quando começaram suas carreiras e que integraram essas problemáticas em suas reflexões, o que contribuiu para a corrente que, atualmente, na ciência política, é a mais científica e próxima da sociologia histórica.

A.G. \& E.P. Atualmente você dirige um Centro que é o prolongamento de uma configuração institucional criada nos anos 1950. E Bourdieu foi central na retomada do legado que começou por Raymond Aron. Como você vê as perspectivas desse conjunto e de sua relação internacional?

G.S. O CSE foi criado em 1958 por Raymond Aron, no momento em que ele criou a graduação em sociologia, portanto são realmente contemporâneos. É nesse momento que ele traz Bourdieu da Argélia, em 1961 ou 1962. Eles são postos em contato, não sei muito bem como. Aron foi ver Bourdieu na Argélia e o ajudou a retornar à França.

A.G. \& E.P. Parece que se teriam conhecido quando Raymond Aron foi presidente do júri do Baccalauréat na Argélia dos anos 1950.

G.S. É possível. Ele trouxe Bourdieu para o CSE e orientou sua reflexão em direção à sociologia. Bourdieu se inscreveu no doutorado com Aron. Muito rapidamente torna-se secretário geral do CSE, em 1961-62. Em 1965, acho, torna-se diretor de estudos na EHESS e, ao mesmo tempo, diretor adjunto do Centro. Depois, por volta de 1968, há uma ruptura política e Bourdieu sai com uma grande parte da equipe. Ele cria o Centre de Sociologie de l'Éducation et 
de la Culture (CSEC). Mesmo depois dessa ruptura, o CSE continuou a existir no Collège de France, mas não era um laboratório do CNRS. Foi o CSEC que se tornou um laboratório do CNRS. Depois da morte de Aron, no Collège de France, Bourdieu recuperou essa estrutura do CSE, que se fundiu com o CSEC, nos anos 1990; em 1997, foi renomeado Centre de Sociologie Européenne, que era mais de acordo com as orientações do laboratório e o projeto europeu que estava em curso. Nessa ampliação, havia menos projetos sobre educação e mais sobre cultura, além de outras temáticas, como a história social das ciências sociais. É o momento também em que se recuperou um pedaço do Centre de Culture et Societé Urbaine (CSU), através da integração de um grupo de pesquisadores ao CSE. Em 2010, fundiu-se com o Centre de Recherche Politique et Sociale (CRPS) da Sorbonne, que é o laboratório de ciência política fundado por Jacques Langrois. Como disse antes, esse Centro agrega cientistas políticos que se caracterizam por seu duplo distanciamento em relação à filosofia política e à sociologia eleitoral. Eles introduziram um paradigma não apenas quantitativo e trabalham com uma verdadeira abordagem científica na ciência política. Grande parte deles fundou a revista Politix. Leram muita sociologia, sobretudo a de Bourdieu, e desenvolveram estudos sobre o engajamento, os movimentos sociais, as instituições políticas, as elites políticas; começaram também a trabalhar sobre o meio político.

No contexto da fusão, havia eixos comuns, um tratava da mundialização, internacionalização e construção europeia; outro da sociologia das elites, que desenvolveu uma parceria com a Universidade de Columbia. Um terceiro eixo era história social das ciências sociais, que existe ainda. Pouco a pouco, outros eixos foram agrupados. Para o próximo quinquênio nosso projeto se redefiniu para um eixo que se chama "going global?", na linha da mundialização, que se caracteriza por uma sociologia do internacional. Não é a maneira clássica de trabalhar sobre as relações internacionais, como essa que existe em ciência política, mas uma sociologia dos atores e das instituições internacionais. Por exemplo, veja o trabalho de Johanna Siméant sobre as ONGs na África. Há um grupo que trabalha sobre a construção europeia, especificamente, sobre o papel dos juristas. Fizeram um estudo prosopográfico, com uma base de dados enorme. É algo que nunca foi feito sobre o perfil dos juristas e sua relação com as elites nacionais: aqueles que investem no exterior, como seus investimentos se fazem no mundo internacional, na Europa, e contribuem para criar essa nova relação. Isto cruza também o eixo que não foi mantido como um eixo separado, o da sociologia das elites. Nós queríamos constitui-lo e agora ele está constituído, especialmente com os trabalhos de François Denord acerca das transformações do campo de poder na França. Denord tem uma equipe que retoma os questionamentos de Bourdieu nos anos 1960 sobre esse assunto. No entanto, ele faz uma grande análise quantitativa do campo de poder na sua atualidade e mostra o aumento do poder econômico e financeiro em rela- 
ção aos capitais anteriormente detidos pelas elites. Decidimos reunir este eixo da sociologia das elites com aquele das relações sociais e de dominação. Ele vai se chamar "Poder e Relações de Dominação", incluindo trabalhos sobre o meio político, o enquadramento de classes populares, a forma de exercer a dominação pelas instâncias dedicadas ao controle dessas classes populares e as novas formas de capital cultural hoje em dia.

A.G. \& E.P. Este assunto foi examinado em um dos últimos números de Actes de la Recherche organizado por Delphine Serre.

G.S. Sim, exatamente. Há uma linha de pesquisa que se chama "Produção, Circulação e Apropriação de Bens Simbólicos", na qual estão incluídos não somente os bens culturais, mas também a produção das opiniões e do consentimento. Além disso, integra esse conjunto a sociologia das mídias, que se desenvolveu bastante no laboratório com os trabalhos de Patrick Champagne e outros sobre o campo de produção cultural, com um novo foco sobre a forma de apropriação das obras, sua recepção, como a pesquisa que fizemos sobre o festival Correspondance de Manosque e sobre o festival de cinema documentário. Uma dimensão dessa pesquisa sobre a divisão do trabalho é a questão do autor na produção cultural. Quem se apropria da posição de autor? Qual a relação entre divisão do trabalho e apropriação do capital simbólico na produção cultural? Outro eixo é a sociologia histórica da ciência, a maior parte voltada para a sociologia e a história das ciências sociais, com o projeto europeu Interco/SSH e a questão da internacionalização e trocas em ciências humanas e sociais na Europa e fora da Europa, com a América Latina, os Estados Unidos, os antigos países colonizados do Sul, para compreender e fazer proposições visando à melhoria das condições de circulação internacional das ideias.

A.G. \& E.P. Você poderia dizer uma última palavra sobre as expectativas de fortalecimento das cooperações internacionais, pois há um vasto programa nesse sentido.

G.S. Penso que a questão internacional deve ser um objeto de pesquisa. Quer dizer, nossos objetos foram construídos nacionalmente, sobretudo na sociologia, o que por vezes se justifica, mas por vezes enviesa, ocultando não somente a dimensão comparativa que permitiria relativizar e historicizar as categorias nacionais, mas também as trocas e as transferências em escala internacional, sem as quais não se podem compreender certas transformações no nível nacional. Por conseguinte, acredito que isso precisa ser desenvolvido em colaborações internacionais por meio de um programa de pesquisa comum. Penso que é preciso trabalhar para desnacionalizar a vida acadêmica, como dizia Bourdieu. Contrariamente ao que se pensa, ela é muito mais nacional do que se pode imaginar. Essa é uma tarefa bem mais difícil do que se pode considerar. Os dados nacionais são efetivamente diferentes. Se qui- 
sermos trabalhar com um conjunto grande de dados nacionais - isso Bourdieu se perguntou em seu programa europeu -, como compará-los, uma vez que não são produzidos da mesma forma? Essa é uma fraqueza induzida pelos efeitos da nacionalização das ciências sociais. As ciências sociais nasceram estritamente ligadas aos Estados nacionais e, por isso, são marcadas por categorias nacionais na produção de dados.

A.G. \& E.P. Muitíssimo obrigado.

Concedida em 05/07/2012 | Aprovada em 06/05/2013

Elina Pessanha é professora do Programa de Pós-Graduação em Sociologia e Antropologia (PPGSA) do Instituto de Filosofia e Ciências

Sociais da Universidade Federal do Rio de Janeiro (UFRJ). Pesquisadora do Conselho Nacional de Desenvolvimento Científico e Tecnológico (CNPq), coordena o Arquivo de Memória Operária do Rio de Janeiro, também na UFRJ. Suas pesquisas abordam os direitos do trabalho, a ativação da justiça pelos trabalhadores e a atuação dos magistrados trabalhistas. Desenvolve também projeto (com José Sergio Leite Lopes, José Ricardo Ramalho e Regina Morel) sobre os precursores da Sociologia do Trabalho no Brasil. É autora (com Glaucia Villas Bôas e Regina Morel) de Evaristo de Moraes Filho - um intelectual humanista (2005) e de Operários navais - trabalho, sindicalismo e política na indústria naval do Rio de Janeiro (2012).

Afrânio Garcia Jr. é antropólogo, mestre de conferências da École de Hautes Études en Sciences Sociales (EHESS) e pesquisador vinculado ao Centre Européen de Sociologie et de Science Politique (CESSP) da Sorbonne. Doutor em Antropologia Social pelo Programa de Pós-Graduação em Antropologia Social (PPGAS/MN-UFRJ), onde foi professor concursado de 1978 a 1998. Foi codiretor do Centre de Recherche sur le Brésil Contemporain (CRBC/EHESS), em parceria com Ignacy Sachs, entre fevereiro de 1996 e novembro de 2009. Seus trabalhos focalizaram modos de dominação e famílias camponesas no Nordeste brasileiro. Atualmente pesquisa mobilidade universitária e circulação internacional das ideias. Prepara, em colaboraçao com Vassili Rivron e Gustavo Sora, um livro sobre a valorizaçao simbólica do Brasil contemporâneo. 


\section{NOTAS}

Os autores e títulos mencionados na entrevista com Gisèle Sapiro estão nas referências bibliográficas [N. E.].

1 Para uma seleção de críticas violentas à Pierre Bourdieu no período pós-1995 até o presente, consultar a biografia de Marie-Anne Lescourret (2008: 12-17).

2 Obra a ser lançada, com tradução de Rosa Freyre de Aguiar, pela Companhia das Letras ainda neste ano.

3 Veja-se o livro resultante de sua livre-docência (Ortiz, 2010).

4 Cabe agradecer ainda ao competente e incansável trabalho de Eduardo Dimitrov e de Maíra Muhringer Volpe, como tradutores e auxiliares de edição dos textos.

5 O Baccalauréat universitaire (BA) equivale ao diploma de graduação brasileiro. Já Maîtrise universitaire (MA) corresponde ao de Mestrado [N.T.].

6 Em 1995, em reação ao plano do então primeiro ministro Alain Juppé (1995-1997) de reforma na aposentadoria e na previdência social, uma série de greves foram deflagradas em diferentes setores (ferroviário, correios, fornecimento de gás e energia elétrica, educação, saúde etc.). Bourdieu, que dois anos antes havia recebido a medalha de ouro do CNRS, e ocupava os mais altos postos de consagração intelectual no sistema francês (na EHESS e no Collège de France), foi um dos poucos intelectuais de grande visibilidade que apoiou o movimento grevista contra os avanços do neoliberalismo e o enfraquecimento do que ele chamou de "a mão esquerda do Estado" [N.T.].

7 De fato, instituída em 1954, a medalha de ouro do CNRS premiou dois antropólogos previamente a Pierre Bourdieu, em 1993: Claude Lévi-Strauss foi agraciado em 1967 e André Leroi-Ghouran em 1973. Da lista até aquele ano constavam, ainda, um historiador e um geógrafo. Em seguida, receberam essa medalha o antropólogo Maurice Godelier, em 2001, o economista Jean Tirole, em 2007, e o antropólogo Philippe Descola, em 2012.

8 A medalha de bronze foi atribuída a Gisèle Sapiro em 2000, por seu livro La guerre des écrivains.

9 Vale lembrar a atuação de Bourdieu na edição da Revista Internacional de Livros Liber que era publicada em francês, 
alemão, italiano, búlgaro, húngaro, sueco, romeno, grego, norueguês e turco. No Brasil, uma coletânea foi editada por Bourdieu, organizada por Sergio Miceli e publicada pela editora da Universidade de São Paulo.

\section{REFERÊNCIAS BIBLIOGRÁFICAS}

Boschetti, Anna. (1985). Sartre et "Les temps modernes". Paris: Les Éditions de Minuit.

Bourdieu, Pierre. (1975). L'invention de la vie d'artiste. Actes de la Recherche en Sciences Sociales, 1, 2, p. 67-93.

Bourdieu, Pierre. (1974). A economia das trocas simbólicas. São Paulo: Perspectiva.

Bourdieu, Pierre \& Miceli, Sergio. (1997). Liber I. São Paulo: Edusp.

Bourdieu, Pierre; Sapiro, Gisèle \& McHale, Brian. (1991). Poetics Today, 12, 4, National Literatures/Social Spaces, Duke University Press, p. 655-669.

Brubaker, Rogers. (1985). Rethinking classical theory: the sociological vision of Pierre Bourdieu. Theory and Society, 14, p. 745-775. Disponível em: <http://works.bepress.com/ wrb/25>. Acesso em 2 mai 2013.

Calhoun, Craig, Lipuma, Edward \& Postone, Moishe. (1993). Bourdieu: critical perspectives. Chicago: University of Chicago Press.

Denord, François, Lagneau-Ymonet, Paul \& Thine, Sylvain. (2001). Le champ du pouvoir en France. Actes de la Recherche en Sciences Sociales, 170, p. 24-57.

Duval, Julien et alii. (1997). Le "Décembre" des intellectuels français. Paris: Raisons d'Agir.

Lescourret, Marie-Anne. (2008). Pierre Bourdieu, vers une économie du bonheur. Paris: Flammarion.

Melo, Manuel Palácios da Cunha e. (1999). Quem explica o Brasil. Juiz de Fora: Ed. UFJF.

Miceli, Sergio. (2001). Intelectuais à brasileira. São Paulo: Companhia das Letras.

Ortiz, Renato. (2010). Trajetos e memória. São Paulo: Brasiliense. 
Ortiz, Renato (org.). (1983). A sociologia de Pierre Bourdieu. São Paulo: Ática, 1983.

Sallaz, Jeffrey \& Zavisca, Jane. (2007). Bourdieu in American Sociology, 1980-2004. Annual Review of Sociology, 33, p. 21-41.

Sand, Shlomo. (2008). Comment le peuple Juif fut inventé. Paris: Fayard.

Sapiro, Gisèle. (2011). La responsabilité de l'écrivain. Littérature, droit et morale en France (XIXe-XXIe siècle). Paris: Seuil. Sapiro, Gisèle. (1999). La guerre des écrivains: 1940-1953. Paris: Fayard.

Sapiro, Gisèle \& Bustamante, Mauricio. (2009). Translation as a measure of international consecration. Mapping the world distribution of Bourdieu's books in translation. Sociologica, 2-3, p. 1-45.

Schneidermann, Daniel. (1999). Du journalisme après Bourdieu. Paris: Fayard.

Serre, Delphine. (2012). Le capital culturel dans tous ses états. Actes de la Recherche en Sciences Sociales, 191-192, p. 4-13. 
42

\section{ENCONTROS COM PIERRE BOURDIEU E DESTINOS DE SUA OBRA-ENTREVISTA COM GISĖLE SAPIRO}

Resumo

A entrevista de Gisèle Sapiro sobre Pierre Bourdieu pertence a um conjunto de textos que visam marcar os 10 anos da morte de Pierre Bourdieu em 2012. A atual diretora do Centre de Sociologie Européenne (CSE), do Centre Européen de Sociologie et de Science Politique de la Sorbonne (CESSP) - apresenta um vasto panorama da recepção da obra de Pierre Bourdieu no mundo internacional, particularmente no anglo-americano. Formada em Israel e vinda da área de literatura comparada, ela narra o encontro com aquele que se tornaria seu professor e orientador de doutorado, e de cuja obra se tornaria grande divulgadora. Inspirada por sua experiência como tradutora, reflete sobre a recepção da obra de Bourdieu pelo mundo, mostrando como as características culturais próprias a cada sociedade criaram ambientes mais ou menos favoráveis a certos aspectos da obra do autor, viabilizando o extraordinário sucesso junto a públicos disciplinares distintos.

\section{ENCOUNTERS WITH PIERRE BOURDIEU AND THE FATES OF HIS WORK-AN INTERVIEW WITH GISÈLE SAPIRO} tor of the Centre de Sociologie Européenne (CSE), associated with the Centre Européen de Sociologie et de Science Politique de la Sorbonne (CESSP), Sapiro offers a broad overview of the international, particularly Anglo-American, reception of Pierre Bourdieu's work. Sapiro studied Comparative Literature in Israel and describes her encounter in Paris with Bourdieu who would become her professor and sponsor and whose work she would propagate. Based upon her experience as translator, Sapiro analyzes the reception of Bourdieu's work, showing how specific cultural features of different societies created a favorable context to certain aspects of Bourdieu's work and made the extraordinary success of Bourdieu's ideas among readers within different disciplines.
Palavras-chave

Gisèle Sapiro; Circulação de ideias; Recepção de ideias; Pierre Bourdieu; Público leitor.

\section{Keywords}

Gisèle Sapiro;

Circulation of ideas; Reception of ideas; Pierre Bourdieu; Readership. 